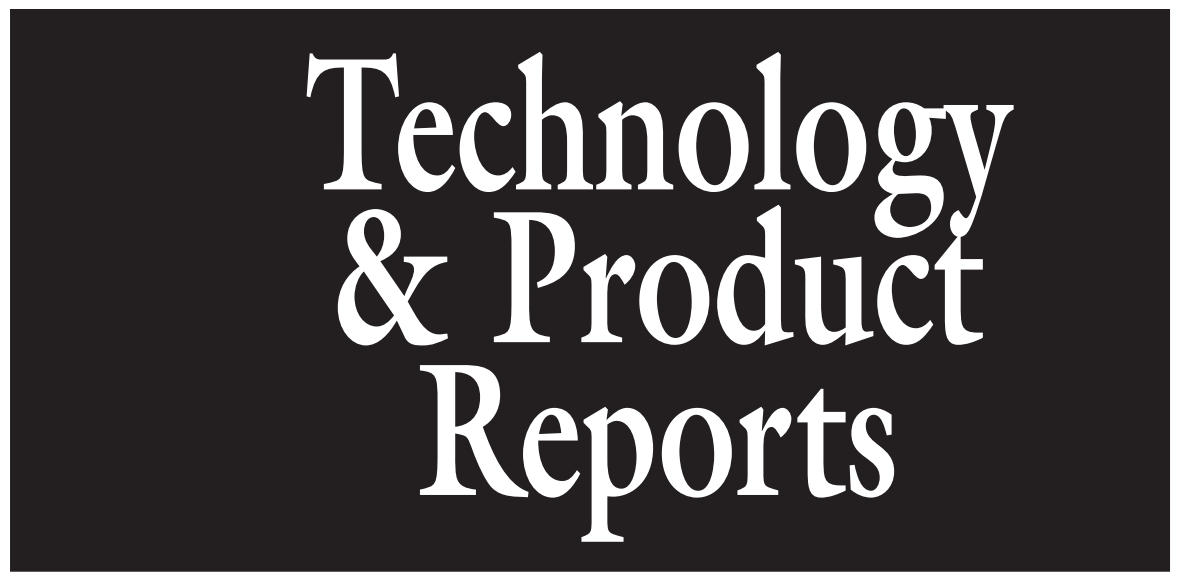

\title{
lodine Staining Does Not Indicate Harvest Maturity of 'Ananasnaya' Hardy Kiwifruit Berries
}

\author{
Connie L. Fisk ${ }^{1}$, Bernadine C. Strik ${ }^{2}$, and Yanyun Zhao ${ }^{1}$
}

AdDitional INDEx wORDs. ${ }^{\circ}$ Brix, percent soluble solids, maturity index, Actinidia arguta

SUMMARY. Iodine staining of starch was explored as a harvest index for hardy kiwifruit (Actinidia arguta). Weekly from 2 Sept. to 14 Oct. 2005, the cut surfaces of 20 halved fruit were dipped in an iodine solution and the staining intensity was measured using digital photography and color analysis. Harvest date had a significant effect on percent soluble solids and each of the color readings $\left(\mathrm{L}^{*}, \mathrm{a}^{*}\right.$, $b^{*}$, and chroma) before and after staining. Fruit harvested later in the season had less starch and thus were lighter in color. However, an observable color difference was only visually apparent weeks after commercial harvest is recommended based on percent soluble solids. Therefore, while the technique can distinguish the conversion of starch to sugar in hardy kiwifruit berries, it cannot be used as a harvest index.

$\mathrm{T}$ The three main species of kiwifruit grown worldwide for fruit production are Actinidia deliciosa, $A$. chinensis, and $A$. arguta, with the former two producing relatively large $(80 \mathrm{~g})$ "fuzzy" fruit compared to the latter, smooth-skinned, small-fruited hardy kiwifruit (Ferguson, 1990). 'Ananasnaya' is the most widely grown cultivar of hardy kiwifruit in the world. Hardy kiwifruit may also be known or marketed under alternate names including "baby kiwifruit," "grape

\footnotetext{
We appreciate the contributions of our grower cooperator, Mark Hurst of Hurst's Berry Farm, Sheridan, Ore., and funding from the Northwest Center for Small Fruits Research.

${ }^{1}$ M.S. Graduate Research Assistant and Associate Professor, respectively, Department of Food Science and Technology, Oregon State University, 100 Wiegand Hall, Corvallis, OR 97331

${ }^{2}$ Professor and Berry Research Leader, NWREC, De partment of Horticulture, Oregon State University, 4017 ALS Building, Corvallis, OR 97331.
}

kiwi," "wee-kee," and "cocktail kiwi." There were 100 acres of 'Ananasnaya' planted in Oregon in 2002 (Tiyayon and Strik, 2003) and Williams et al. (2003) estimated that about 100 ha were grown commercially worldwide, in the United States (Oregon, Pennsylvania, New York, and Washington), New Zealand, Canada (British Columbia and Ontario), Chile, Italy, France, Germany, and The Netherlands.

The fruit of 'Ananasnaya' is a medium-sized, ovoid ( 1.5 inch long $\times 1$ inch wide) berry. Fruit weight ranges from 2 to $14 \mathrm{~g}$, averaging $6.9 \mathrm{~g}$ (Pescie and Strik, 2004) or 7.3 g per vine ( $\mathrm{Ti}^{-}$ yayon and Strik, 2004). 'Ananasnaya' produces a green to red-blushed berry with a smooth, edible skin. The flesh is light green, juicy, and has a sweettart taste with a rich, aromatic flavor that has been compared to ripe pineapple (Ananas comosus), strawberries (Fragaria $\times$ ananassa), bananas (Musa spp.), European gooseberries (Ribes spp.), over-ripe pears (Pyrus spp.), or rhubarb (Rheum spp.) (Ferguson and Ferguson, 2003). The sliced fruit has a similar internal appearance to that of the more typical "fuzzy" 'Hayward' kiwifruit (A. deliciosa) (Ferguson, 1984).

'Ananasnaya' has female flowers that bloom for about $10 \mathrm{~d}$ in late May to early June. Fruit go through an initial phase (35 to $40 \mathrm{~d}$ after flowering) of rapid increase in fruit volume, followed by a period of reduced growth, which may coincide with seed hardening (from 35 to $50 \mathrm{~d}$ after flowering). Fruit thereafter continue to increase in volume and reach maximum size approximately 2 weeks to 1 month prior to harvest, depending on harvest criteria (Pescie and Strik, 2004). Hassall et al. (1998) reported that hardy kiwifruit in New Zealand reached $80 \%$ of final size by $40 \mathrm{~d}$ after flowering. Fruit mature in late summer to autumn, 100 to $110 \mathrm{~d}$ after flowering, depending on region, with firmness decreasing in the later stages of ripening (Kabaluk et al., 1997; Strik, 2005).

Commercially, fruit are all hand harvested in Oregon, when soluble solids average $8 \%$ to $10 \%$ (Strik, 2005; Tiyayon and Strik, 2003). In New Zealand, new selections of hardy kiwifruit were ideally harvested at $20 \%$ dry weight; fruit harvested earlier developed storage disorders and did not reach as high percent soluble solids when ripened (Williams et al., 2003). When harvesting at average $8 \%$ to $10 \%$ soluble solids, most fruit are still green and firm, although a small percentage (generally less than $4 \%$ of total yield) are very soft and unusable

\begin{tabular}{llll}
\hline $\begin{array}{l}\text { Units } \\
\begin{array}{l}\text { To convert U.S. to SI, } \\
\text { multiply by }\end{array}\end{array}$ & U.S. unit & SI unit & $\begin{array}{l}\text { To convert SI to U.S., } \\
\text { multiply by }\end{array}$ \\
\hline 0.4047 & acre(s) & ha & 2.4711 \\
3.7854 & gal & L & 0.2642 \\
2.54 & inch(es) & cm & 0.3937 \\
25.4 & inch(es) & mm & 0.0394 \\
28.3495 & oz & g & 0.0353
\end{tabular}


(Tiyayon and Strik, 2003). Hassall et al. (1998) reported hardy kiwifruit in New Zealand were harvested when about $10 \%$ of the fruit on a vine were soft to the touch. Fruit cannot be harvested vine ripe. Vine ripe fruit are too soft to handle or store and often the fruit tears at the pedicel-fruit juncture when harvested. In Aurora, Ore. fruit reached a typical commercial harvest of $8 \%$ to $10 \%$ soluble solids on 21 Sept. However, vine-ripened fruit continued to increase in soluble solids to $21 \%$ to $23 \%$, depending on cultivar (Strik and Hummer, 2006).

Acommercial grower's decision to harvest is influenced by seed color (all seeds must be black), average percent soluble solids, and percent of fruit prematurely softening. Unfortunately, hardy kiwifruit do not ripen uniformly on the vine (Kabaluk et al., 1997; Strik and Tiyayon, 2003), making determination of optimum date for once-over harvest difficult. Dry weight of fruit continues to increase with or without a sharp rise in content of soluble solids (Hassall et al., 1998). Also, the fruit change little in external color during the optimum harvest period. Variable fruit quality due to range in fruit size, percent soluble solids, firmness, and subsequent flavor is considered an important production problem in this crop.

Development of a rapid, simple, inexpensive, in-field test for predicting optimum harvest date would be of great benefit to the hardy kiwifruit industry. Iodine staining of starch has been used to help judge maturity in apples (Malus spp.; Saltveit and Hale, 1982), pears (North, 1961 as cited by Blankenship et al., 1993), and bananas (Blankenship et al., 1993). In 'Hayward' kiwifruit, starch content of fruit declines as seeds change from brown to black and as fruit ripens with a consequent increase in sugars (Beever and Hopkirk, 1990; Cheah and Irving, 1990). At harvest, the starch content of 'Hayward' accounted for 5\% to 7\% of the fresh weight or $35 \%$ of the dry weight (MacRae et al., 1989a, 1989b). By the time fruit are ready to be eaten, starch has completely degraded and sugar content is three- to four-fold greater than at harvest (MacRae et al., 1989b). Iodine staining of starch is thus closely correlated with percent soluble solids and may be useful in hardy kiwifruit. Producing a color reference chart of staining patterns that could be taken into the field and compared to stained fruit may help growers predict optimum harvest date. The purpose of this study was to determine if a useful iodine-starch staining test could be developed in 'Ananasnaya' to estimate percent soluble solids and thus optimum harvest date.

\section{Materials and methods}

Fruit MATERIAL. Berries of 'Ananasnaya' were harvested weekly from 2 Sept. to 14 Oct. 2005 from a mature commercial vineyard in Sheridan, Ore. Twenty representative fruit were picked each week from four plants trained to a pergola, with care paid to harvest from various locations in the canopy. The fruit were immediately transferred to the Value Added Fruit and Vegetable Processing Lab at Oregon State University, Corvallis, and were allowed to come to room temperature before analysis. Fruit were cut in half in cross-section, with one-half subjected to measurement of percent soluble solids (refractometer RA-250, KEM; Kyoto Electronics Manufacturing Co., Ltd., Kyoto, Japan) and the other half used for iodine-starch staining and color measurement. Measurement of percent soluble solids was done on the half proximal to the pedicel on half of the sampled fruit and distal to the pedicel on the other half, in case percent soluble solids varied from the pedicel to the calyx end of the fruit (MacRae et al., 1989a, 1989b). Juice was extracted from the sliced fruit by squeezing.

IODINE-STARCH STAINING. The iodine staining solution $(1.0 \%$ potassium iodide, $0.1 \%$ iodine; Mallinckrodt Baker, Inc., Phillipsburg, N.J.) was prepared as described by Saltveit and Hale (1982). Briefly, potassium iodide was dissolved in a small amount of deionized water before addition of iodine, and then deionized water to make $1 \mathrm{~L}$. One half of each fruit was placed cut side down in $5 \mathrm{~mm}$ of staining solution for $1 \mathrm{~min}$. Fruit were then gently rinsed with deionized water and blotted with tissue paper to remove excess moisture. Samples were allowed to dry briefly before color measurements and digital photographs were taken.

Color AnAlysis. The flesh color of each sliced fruit was measured before and after staining using a Hunter Labscan spectrophotometer (model
MS/S-4500L; Hunter Associates Laboratory, Inc., Reston, Va.). The instrument parameters used were a mode of $0 / 45$, a $10^{\circ}$ Observer, D65 sodium aluminates, and a port size of 1.7-cm diameter. The $\mathrm{L}^{*}$ (lightness), $\mathrm{a}^{*}$ (redness-greenness), and $b^{*}$ (yellowness-blueness) values were recorded. White $\left(\mathrm{L}^{*}=92.95, \mathrm{a}^{*}=0.67, \mathrm{~b}^{*}=\right.$ 2.16) and black plates were used to standardize the machine, and green plate was used as a color reference $\left(\mathrm{L}^{*}{ }_{\text {ref }}\right.$ $\left.=54.71, \mathrm{a}^{*}{ }_{\text {ref }}=-27.22, \mathrm{~b}^{*}{ }_{\text {ref }}=16.53\right)$. Calculated chroma $\left(\left(a^{* 2}+b^{* 2}\right)^{1 / 2}\right)$ values were also used for comparing color changes between samples before and after staining. Digital photographs were taken using a Sony model DSCS85 camera (Sony Corp., Tokyo).

Data were analyzed using SAS (SAS Institute Inc., Cary, N.C.). Color readings, before and after iodine staining, were analyzed using a paired $t$ test. The effect of harvest date on percent soluble solids and color readings was analyzed using PROC GLM. The relationship between color readings and percent soluble solids was analyzed using regression and correlation.

\section{Results and discussion}

Harvest date had a significant effect on the measured variables, percent soluble solids and each of the color readings, before and after staining $(P$ $<0.0001)$. Changes in percent soluble solids over the harvest period are presented (Fig. 1) and were similar to what has been reported elsewhere for this cultivar of hardy kiwifruit (Kabalak et al., 1997; Strik and Hummer, 2006; Tiyayon and Strik, 2004).

The appearance of sliced fruit after staining with iodine was affected by percent soluble solids (Fig. 2). Ripe fruit (higher percent soluble solids) had less starch and thus showed less color change after staining with iodine. The $\mathrm{L}^{*}, \mathrm{a}^{*}, \mathrm{~b}^{*}$, and chroma values were significantly affected by staining $(P<$ 0.05 ) on all harvest dates even on the last fruit harvest date when percent soluble solids averaged 15.3 and there was little visual change in color after staining (Fig. 2).

The correlation between $\mathrm{L}^{*}$ after staining and percent soluble solids was affected by harvest date (Fig. 3). Fruit harvested later in the season had less starch and thus were lighter after staining (Figs. 2 and 3 ). With the exception of the 30 Sept. harvest date, the range 


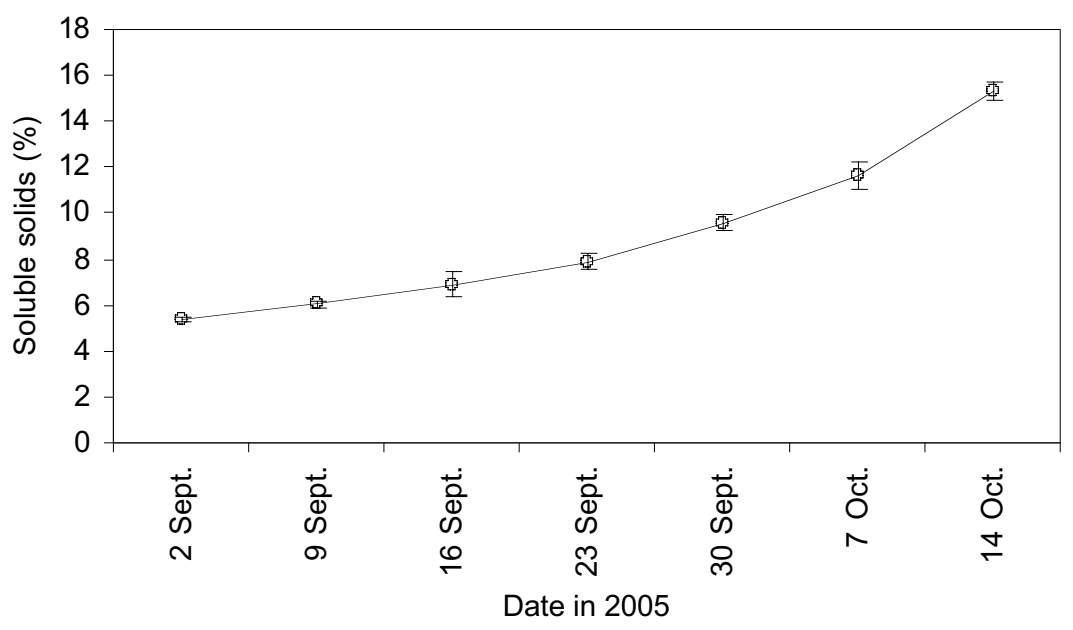

Fig. 1. The effect of harvest date on percent soluble solids of 'Ananasnaya' fruit $(n=20$, mean \pm SE per date $)$.

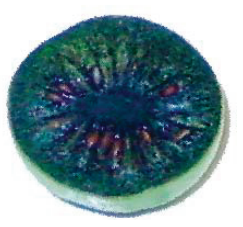

4.5

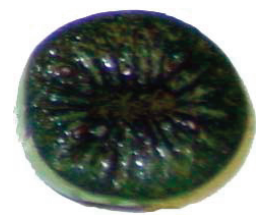

7.5

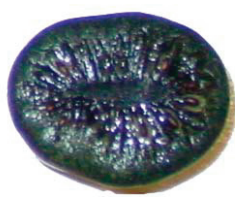

11.5

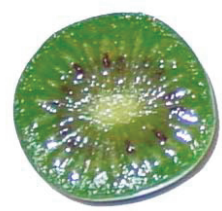

15.5
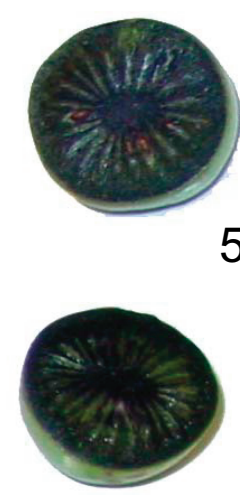

8.5

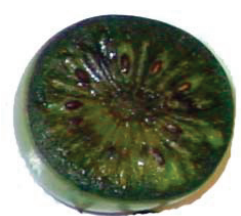

12.5

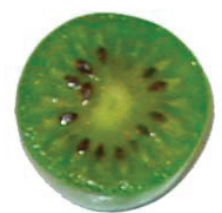

16.5
5.5
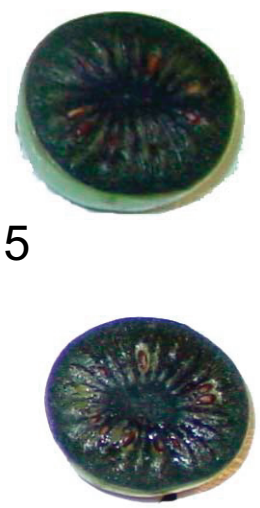

9.5

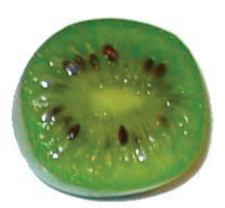

13.5

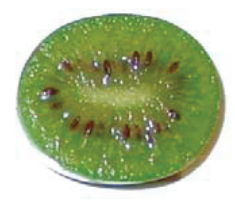

17.5

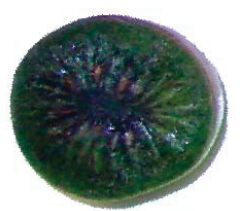

6.5

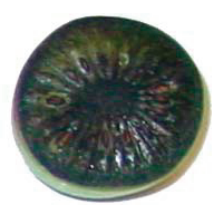

10.5

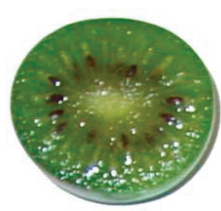

14.5

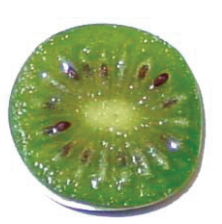

18.5
Fig. 2. Visual appearance of 'Ananasnaya' fruit, ranging from $4.5 \%$ to $18.5 \%$ soluble solids, after staining with iodine. in $L^{*}$ readings among sampled fruit (standard deviation) was greater as the harvest date progressed (Fig. 3); we are unsure as to the cause of this variation. At $13.5 \%$ soluble solids, fruit had visually lost evidence of staining (Fig. 2).

On 30 Sept., when percent soluble solids was within the present commercial standard for harvest, $8 \%$ to $10 \%$ (Fig. 1), percent soluble solids was significantly correlated $(P<0.05)$ with $L^{*}(r=-0.465)$ and $a^{*}(r=0.541)$ before staining and $\mathrm{L}^{*}(\mathrm{r}=0.601), \mathrm{b}$ * $(\mathrm{r}=0.591)$, and chroma $(\mathrm{r}=0.495)$ after staining. Similar correlations were observed for the 23 Sept. harvest date (data not shown). Each of the variables was correlated with percent soluble solids for fruit harvested on 16 Sept. However, there were no significant correlations between percent soluble solids and each of the color variables before or after staining for fruit harvested on 2 or 9 Sept. when soluble solids was $5 \%$ to $6 \%$ (data not shown).

There was no clear pattern to which parts of the sliced kiwi were more stained than others. In apple the core loses staining ability last (Saltveit and Hale, 1982) and in banana starch (and staining) is lost from the center of the fruit outward (Blankenship et al., 1993). In our study, fruit at all percent soluble solids levels could show spots that did not stain, but the locules in particular were less stained than the columella (core; Fig. 2).

\section{Conclusions}

Results demonstrate that hardy kiwifruit can be successfully stained using the iodine staining technique. However, although each of the color variables $\left(\mathrm{L}^{*}, \mathrm{a}^{*}, \mathrm{~b}^{*}\right.$, and chroma) was correlated with percent soluble solids, it was difficult to discriminate color change visually at a desirable harvest percent soluble solids. In general, the color change seen after staining with iodine occurred after the best time for harvest. Also, the degree of staining was variable enough, within a narrow range of percent soluble solids, for concern as to the accuracy of this technique for predicting sugar content of fruit. Thus, growers should continue to use a refractometer for measuring percent soluble solids when determining harvest date in this crop. 


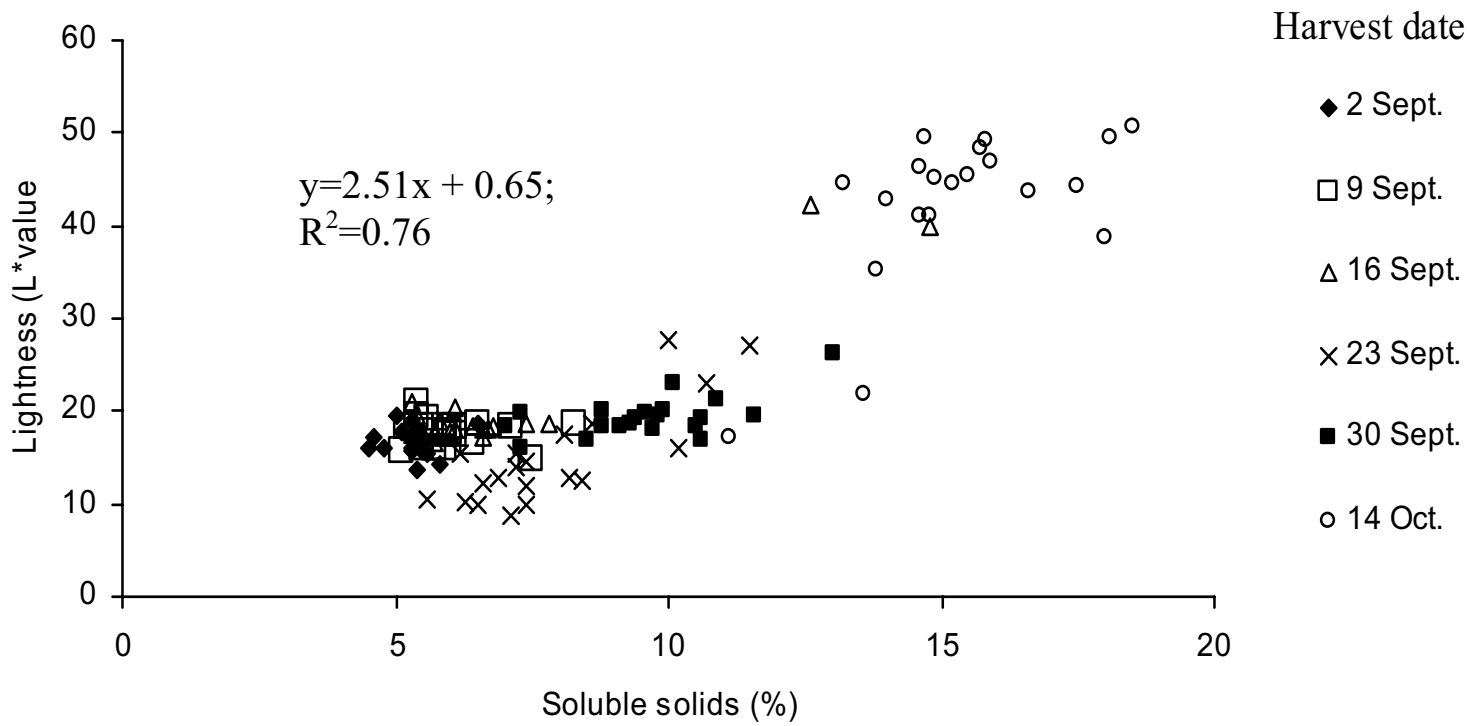

Fig. 3. The relationship between lightness $\left(\mathrm{L}^{*}\right)$ after iodine staining and percent soluble solids of 'Ananasnaya' fruit across harvest dates in $2005(\mathrm{n}=20$ per harvest date).

\section{Literature cited}

Beever, D.J. and G. Hopkirk. 1990. Fruit development and fruit physiology, p. 97126. In: I.J. Warrington and G.C. Weston (eds.). Kiwifruit science and management, N.Z. Soc. Hort. Sci., Wellington, N.Z.

Blankenship, S.M., D.D. Ellsworth, and R.L. Powell. 1993. A ripening index for banana fruit based on starch content. HortTechnology 3:338-339.

Cheah, L.H. and D.E. Irving. 1990. Kiwifruit, p. 209-227. In: I.J. Warrington and G.C. Weston, (eds.). Kiwifruit science and management, N.Z. Soc. Hort. Sci., Wellington, N.Z.

Ferguson, A.R. 1984. Kiwifruit: A botanical review. Hort. Rev. 6:1-64.

Ferguson, A.R. 1990. The genus Actinidia, p. 15-35. In: I.J. Warrington and G.C. Weston, (eds.). Kiwifruit science and management, N.Z. Soc. Hort. Sci., Wellington, N.Z.

Ferguson, A.R. and L.R. Ferguson. 2003. Are kiwifruit really good for you? Acta Hort. 610:131-137.
Hassall, A.K., G.J. Pringle, and E.A. MacRae. 1998. Development, maturation, and postharvest responses of Actinidia arguta (Sieb. et Zucc.) Planch. ex Miq. fruit. N.Z . J. Crop. Hort. Sci. 26:95-108.

Kabaluk, J.T., C. Kempler, and P.M.A. Toivonen. 1997. Actinidia arguta-Characteristics relevant to commercial production. Fruit Var. J. 51:117-122.

MacRae, E.A., J.H. Bowen, and M.G.H. Stec. 1989a. Maturation of kiwifruit ( $A c$ tinidia deliciosa cv. Hayward) from two orchards: Differences in the composition of the tissue zones. J. Sci. Food Agr. 47:401-416.

MacRae, E.A., N. Lallu, A.N. Searle, and J.H. Bowen. 1989b. Changes in the softening and composition of kiwifruit (Actinidia deliciosa) affected by maturity at harvest and postharvest treatments. J. Sci. Food Agr. 49:413-430.

Pescie, M. and B. Strik. 2004. Thinning before bloom affects fruit size and yield of hardy kiwifruit. HortScience 39:1243-1245.
Saltveit, M.E. and S.A. Hale. 1982. Determining the maturity of North Carolina apples. North Carolina Agr. Ext. Bul. AG-282.

Strik, B. 2005. Growing kiwifruit. Oregon State University Ext. Serv. Publ. PNW 507.

Strik, B.C. and K.E. Hummer. 2006. 'Ananasnaya' hardy kiwifruit. J. Amer. Pomol. Soc. 60:106-112.

Tiyayon, C. and B. Strik. 2003. Flowering and fruiting morphology of hardy kiwifruit, Actinidia arguta. Acta Hort. 610:171-176.

Tiyayon, C. and B. Strik. 2004. The influence of time of overhead shading on yield, fruit quality, and subsequent flowering of hardy kiwifruit, Actinidia arguta. N.Z. J. Crop Hort. Sci., 32:235-241.

Williams, M.H., L.M. Boyd, M.A. McNeilage, E.A. MacRae, A.R. Ferguson, R.A. Beatson, and P.J. Martin. 2003. Development and commercialization of 'Baby Kiwi' (Actinidia arguta Planch.). Acta Hort. 610: 81-86. 